\title{
ABSOLUTE RADIOCARBON CHRONOLOGY IN THE FORMATIVE POTTERY PRODUCTION CENTER OF SANTA LUCÍA, COCHABAMBA, BOLIVIA
}

\author{
Olga U Gabelmann ${ }^{1} \bullet$ Adam Michczyński $^{2,3} \bullet$ Anna Pazdur $^{2}$ • Jacek Pawlyta ${ }^{2}$
}

ABSTRACT. Santa Lucía is a pottery production site dating to the Formative period (about 1600 BC to AD 200). It is located in the Cochabamba valleys of the eastern Bolivian Andes. The settlement consists of a residential area and a separate workshop area. A peripheral sector of ash mounds was used as refuse sites and burial grounds. The excavations yielded a total of 16 radiocarbon samples from all 3 sectors, which were dated at the Gliwice Radiocarbon Laboratory (Gliwice, Poland). The results from the deepest trench in the workshop sector (Trench 5) provide information for the stratigraphic sequence and help to define spatial and socioeconomic changes at around 600-500 BC with the beginning of the Late Formative or Santa Lucía III phase. The ${ }^{14} \mathrm{C}$ dates from Santa Lucía, therefore, contribute to a better definition of the existing regional Formative period phases and finally to a better understanding of the processes during the Formative period in the south-central Andes.

\section{INTRODUCTION}

Santa Lucía is a large pottery production center with a size of 16.08 hectares. It was assigned to the Formative period, spanning a time from about $1600 \mathrm{BC}$ to AD 200 in Bolivia. The site is located near the modern town of Cliza $\left(17^{\circ} 35^{\prime} \mathrm{S}, 65^{\circ} 56^{\prime} \mathrm{E}\right)$ at $2735 \mathrm{~m}$ asl and lies in the center of the Valle Alto, the largest of the 5 Cochabamba valleys in the eastern Andean slopes.

The site was briefly surveyed by Dick Edgar Ibarra Grasso in the 1950s. His results were published without greater details in comprehensive prehistory books (Ibarra Grasso 1962:336; Ibarra Grasso and Querejazu Lewis 1986:150) and other papers. Two radiocarbon dates taken by Geraldine Byrne de Caballero in 1972 are reported to derive from Santa Lucía (Ziółkowski et al. 1994:93). However, their true origin remains vague since in our investigation we could not find any Tiwanaku occupation (as specified for the samples), unless it had been completely washed away within the past $30 \mathrm{yr}$. The present investigation (Proyecto Santa Lucía) represents the first systematic research at the site.

Only a few other Formative period sites in the Cochabamba area have been excavated and published so far (Rydén 1961; Walter 1966; Brockington et al. 1985, 1987, 1995; Gabelmann 2001). Some provided absolute ${ }^{14} \mathrm{C}$ dates for site comparisons and served to establish a local Formative chronology from $1100 \mathrm{BC}$ to AD 600, divided into Early, Middle, and Late Formative phases (Brockington et al. 1987, 1995; Pereira Herrera and Brockington 2000). To date, however, no significant characteristics or changes were defined for each stage. Therefore, absolute dating of the site of Santa Lucía will be a helpful contribution to refine that chronology, even more so, as we have evidence of socioeconomic changes linked to a high level of ceramic production in separate workshops, which are uncommon for the Formative period.

\section{SITE DESCRIPTION}

The surface of Santa Lucía is covered by architectural remains and structures as well as a dense scattering of potsherds and stone artifacts. Most frequent are circular or oval piles of red-baked clay fragments that are the remnants of firing facilities (kilns) for the pottery production. These structures showed no signs of a fuel chamber. This information indicates that the technology used for firing was the "open fire" method, which was very common in the Andes in pre-Hispanic times and is still

\footnotetext{
${ }^{1}$ Freie Universität Berlin, ZI Lateinamerika-Institut, Rüdesheimer Str. 54-56, 14197 Berlin, Germany.

${ }^{2}$ Silesian University of Technology, Institute of Physics, Radiocarbon Laboratory, GADAM Centre of Excellence, Bolesława Krzywoustego 2, 44-100 Gliwice, Poland.

${ }^{3}$ Corresponding author. Email: Adam.Michczynski@polsl.pl.
}

C 2009 by the Arizona Board of Regents on behalf of the University of Arizona Proceedings of the 5th International ${ }^{14} \mathrm{C}$ and Archaeology Symposium, edited by Irka Hajdas et al. RADIOCARBON, Vol 51, Nr 2, 2009, p 501-513 
used in some parts of the world (Rice 1987:154). It is likely, deducing from some angular and curved burned clay fragments, that these facilities were originally "platforms" or "basins" with some kind of lower walls. About 230 of such "open kilns" in a more or less eroded state were counted on the surface.

Further, domestic structures were also found on the surface. Circular habitation structures with a 4 $6 \mathrm{~m}$ diameter were detected in the form of floor or wall foundations made of pebbles or small stones. Especially, house C5 (see Figure 1, close to Trench 9) is of interest, since it presents a visible entrance and a compact clay floor inside with a central posthole for the construction of a conical roof. Smaller circular or oval structures with a $\sim 2-3.5 \mathrm{~m}$ diameter were most likely storage facilities.

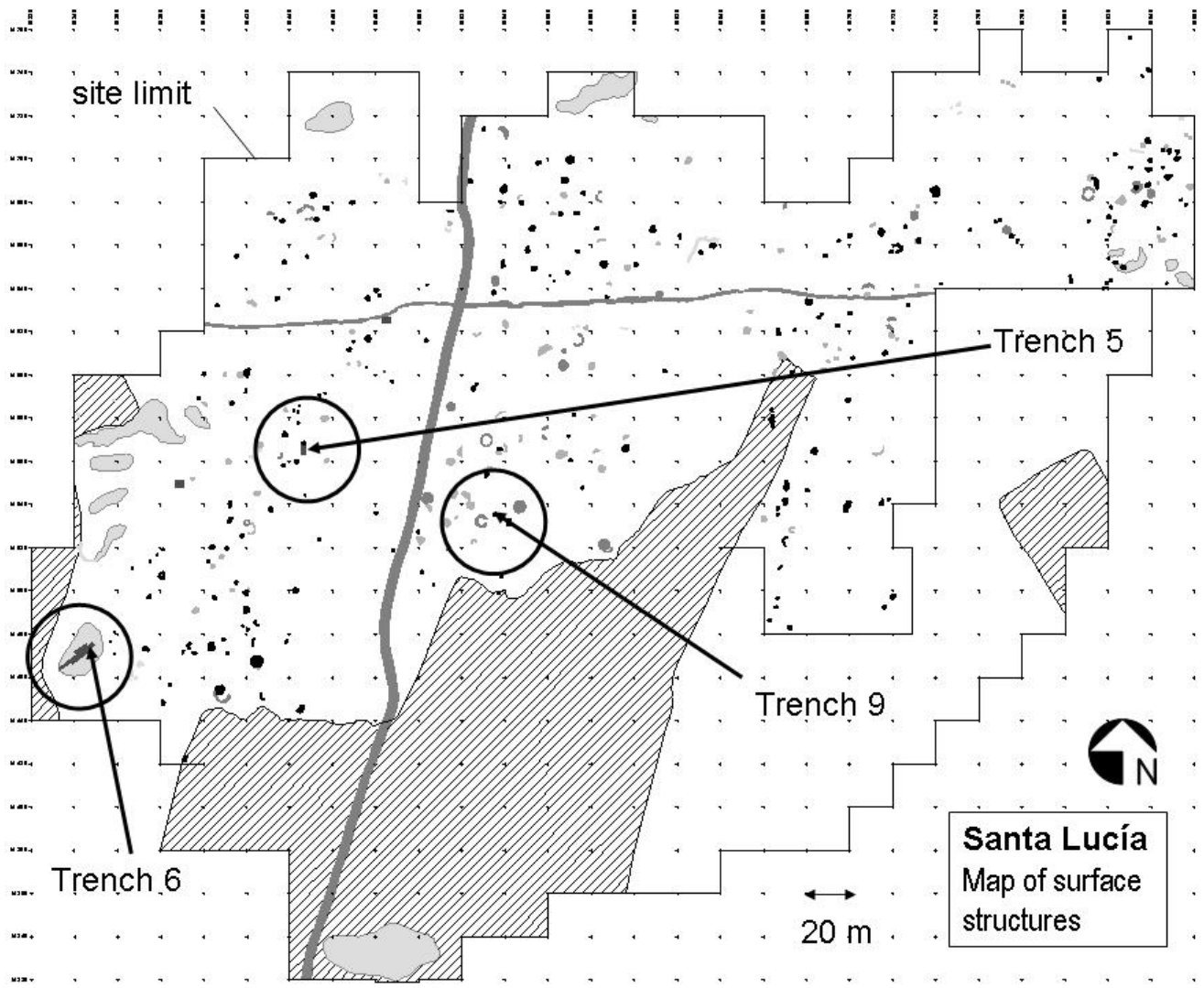

Figure 1 General site plan of Santa Lucía. Black: firing facilities; dark gray: houses; light gray: storage structures, light gray with dark gray lines: ash mounds. Circles show locations of trenches from which the samples were collected.

A general site plan, presented in Figure 1, shows the firing platforms marked in black, houses in dark gray, and storage structures marked in light gray color. Note the clear concentration of domestic structures accompanied by a few firing platforms in the center of the site, which is likely the residential area. Moreover, we can observe an almost ring-like concentration of firing facilities and several small storage structures surrounding the center. This workshop or production area is spatially separated from the household. On the site's periphery exist some eroded mounds (in Figure 1 marked as large light gray spots surrounded by a gray line), which follow the western site limits from south to north in a semicircle. The mounds consist of a very soft dark soil with a high percent- 
age of ash, and they also contain human bones. Therefore, they were not only used to deposit the ashes from the firing area, but also for "depositing" bodies.

We can distinguish 3 different functional sectors in Santa Lucía-domestic, production, and deposit or burial areas-which have been subject to further excavation (trenches 5, 6, and 9). Each of the trenches was placed in a different sector (see Figure 1). Samples for ${ }^{14} \mathrm{C}$ dating were taken from all trenches.

\section{EXCAVATION}

Trench 5 was excavated to a depth of $3.65 \mathrm{~m}$, yielding a stratigraphy with a succession of floor and fill layers, until human artifacts almost disappeared in the lowest stratum of hard clay (Figure 2). The profile shows the occupation sequence of Santa Lucía in the western workshop sector. The trench was excavated cutting through a firing facility (indicated as 12 in Figure 2) on the surface in the northern end of the trench. At $2.5 \mathrm{~m}$ distance from the firing platform and only $10 \mathrm{~cm}$ below the surface, a destroyed hearth made of burned clay appeared together with pieces of charcoal. The samples SL-C22, -C34, and -C37 stem from this hearth. A hard compact clay layer (1) stretches all the way to the platform. This layer can be interpreted as an outside activity area, either related to food preparation and cooking or for preheating the vessels. The finds of a grinding stone and a clodbreaker next to the hearth can again be regarded as either linked to domestic (food preparation) or productive activities (beating clay lumps, smoothing the surface of raw vessels). Nevertheless, this level was called "domestic hearth phase," even though its purpose is not clear. The proximity to the firing platform allows us to assume that both units were in contemporary use.

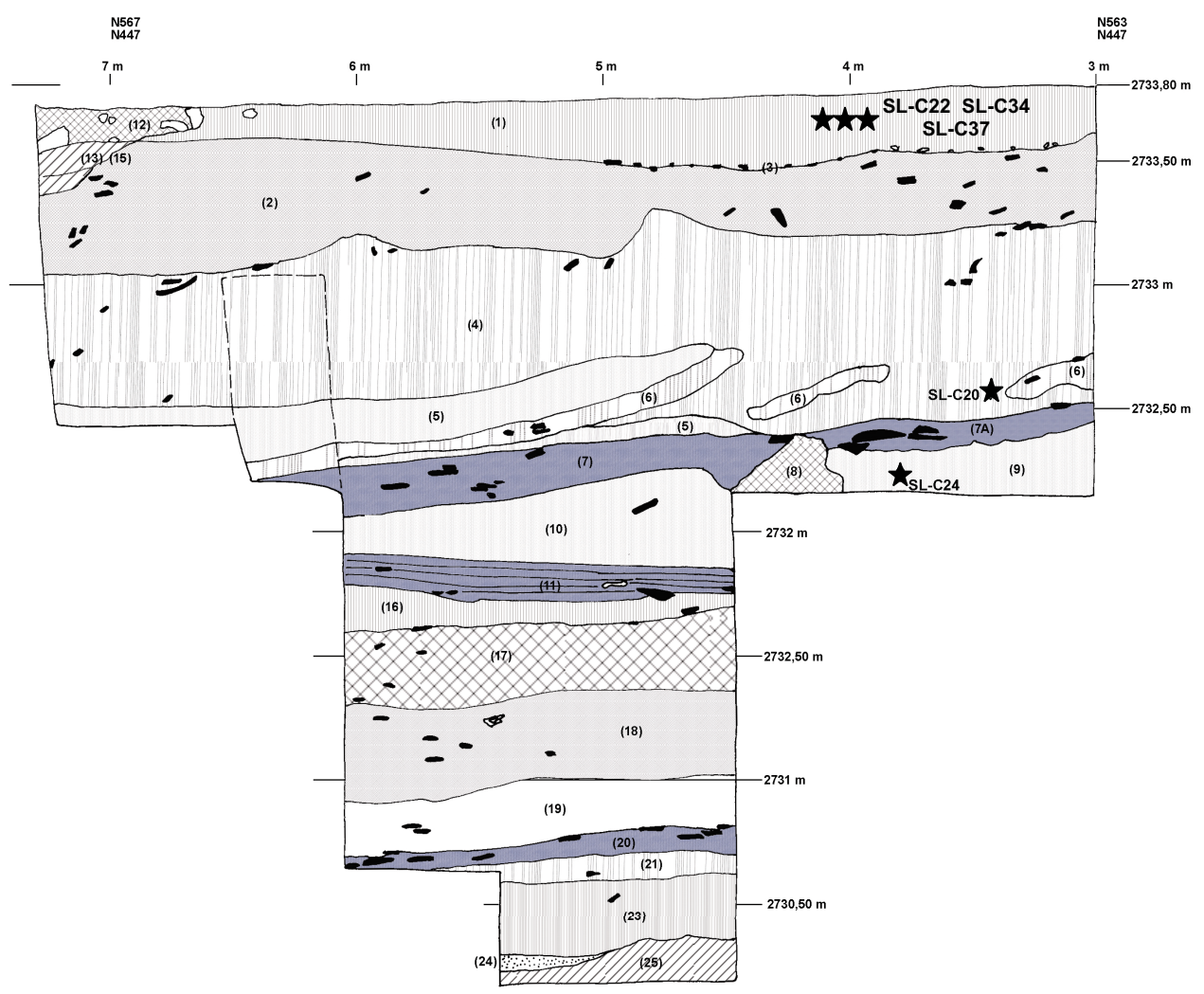

Figure 2 East profile of Trench 5. Locations of samples are marked by stars, house floors in dark gray. 
Apart from the 3 charcoal samples from the uppermost level ("domestic hearth phase"), we obtained 2 more samples from this trench. At a depth of about $60 \mathrm{~cm}$, a thick semi-compact to soft fill of clay, sand, and ashes appeared with small raw and burned clay fragments (4). While the upper part presented a homogenous mix of all ingredients, in the lower part layers of compact clay and soft ashes associated with ceramic production alternated in diagonal orientation, as would be the case in a waste deposit. Sample SL-C20 comes from this lower part, dating the beginning of a massive, 70to 80 -cm-thick fill layer.

This fill layer lies on top of a very compact clay floor (7) of 12-20 cm thickness and a similar but thinner floor (7A) adjacent to it, both of which were slightly inclined towards the north. Floor 7A may be interpreted as an outside activity area separated from the former by a big chunk of yellow clay (8). Underneath, there is another fill (9) with a similar composition like the upper fill layer (4). From this stratum (9), we obtained sample SL-C24. Due to a reduction in size of the pit at this depth, we cannot determine the relation between the fill layers 10 and 9, but it is likely the same layer. Therefore, sample SL-C24 gives us a terminus post quem and SL-C20 a terminus ante quem for the occupation of house floor (7) and the outside activity area (7A). Floors 7 and 7A were separated by the soft fill layer (10) from an earlier house floor level (11) of similar hard clay material. This floor level can be dated with SL-C24 as a terminus ante quem.

Unfortunately, no further samples were available for dating the lower levels of Trench 5. A third floor level was found in the lower part (20). It is clear, therefore, that the date of SL-C24 is far from presenting the oldest occupation of Santa Lucía.

Trench 9 was placed in the residential sector located in the center. A waste pit (H21), visible on the surface in front of house $\mathrm{C} 5$, was excavated. This pit was about $60 \mathrm{~cm}$ deep and intrusive to older layers, as shown in the profile drawings (Figure 3B). Its contents were associated with ceramic production, but also with domestic refuse. It yielded abundant fragments of burned clay and clay slag, which seem to come from a nearby overheated firing facility. In the lower part, we found a thick layer of fine white and gray ash with organic material. Seeds of tara (Caesalpina tinctoria) and molle (Schinus molle) indicate that these trees had probably been used as fuel wood. From this locus, we obtained a charcoal sample (SL-C47), which may also date the use of house C5 or its near abandonment.

Only a few $\mathrm{cm}$ below the bottom of the waste pit, 2 large intrusive storage vessels appeared. They showed no significant contents. One was covered with a shallow bowl as a lid; the other vessel was destroyed in the neck part, probably during the intrusion of the waste pit. The profiles (Figure 3A,B) show the relation of the vessels with a 50-cm-thick fill layer (2). The material of the pits dug for their deposition is the same as the fill layer (2). From this layer, we obtained sample SL-C41, which dates both the time of its accumulation and the contemporary deposition of the storage vessels.

Trench 6 (see Figure 4) was cut through one of the ashy mounds (MO1) in the westernmost sector of the site; it has a total length of $21 \mathrm{~m}$ and a width of up to $3 \mathrm{~m}$. The western part of the trench shows compact sandy clay with an extension of about $6 \mathrm{~m}$. This part may be interpreted as a flattened embankment or dike that separated the village from an old riverbed. The latter was detected through the sedimentation of pebble layers just below the western part of the embankment. To the east, we see a thick package of ashy soft sand of different hues of dark-gray-brown alternating with thin layers of raw clay material, charcoal, and a few baked clay fragments. Only close to the surface does this layer package appear to have been altered by more recent use of this area, with intrusive pits and a colonial-period floor layer. The ash deposits are 1.2-1.4 m thick, but seem to have accumulated over a rather short time. It is most likely that they are the result of cleaning the firing platforms, since 


\section{Trench 9}

North Trench Profile

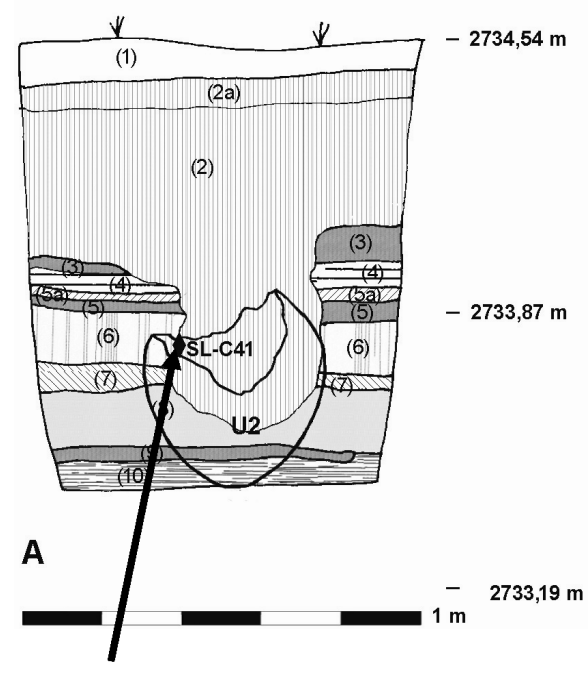

Location of radiocarbon sample
East Trench Profile

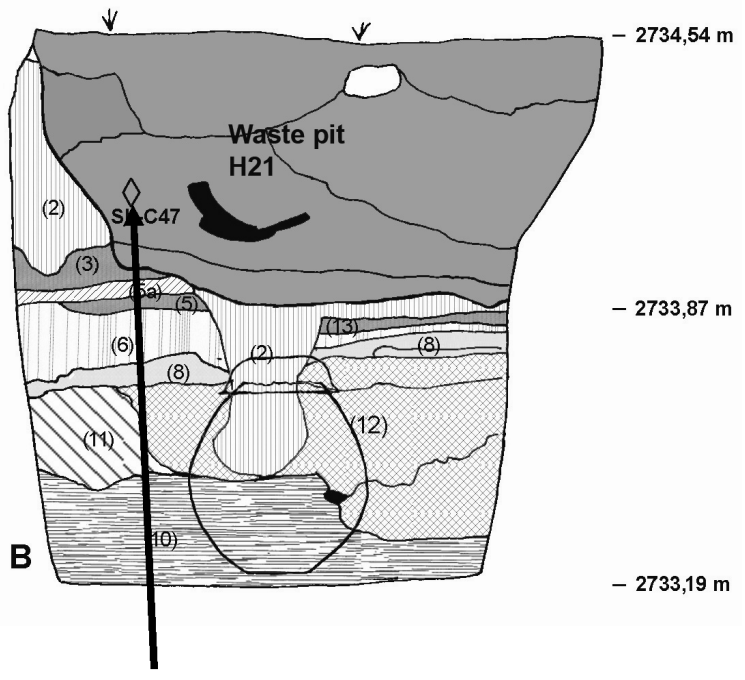

Location of radiocarbon sample

Figure 3 North and east profile of Trench 9

the use of the open-fire technology supposedly left a lot of ashes. With chunks of raw and baked clay, the ash layers are clearly associated with the waste resulting from the ceramic production.

Several burials were found at different levels in the ash layers. They were deposited without any definable construction or a pit and were covered with the same ashy soil. Most of the bodies were disturbed through the rearrangement of the ash layers. The placement of burials in this context seems a bit odd, suggesting the notion of a disposal rather than a burial for the dead. Yet the find of a young camelid offering and the presence of large storage vessels, which had been smashed on the spot, show activities that can be linked to a kind of ritual that took place in this area, while the first bodies were being deposited, or to prepare these grounds for the burials. The vessels were found in the lower level of the dark ash layers; therefore, this level was called the "smashed vessel horizon."

From the lower strata, we obtained several ${ }^{14} \mathrm{C}$ samples. Seven samples (SL-C6, -C9, -C11, -C12, $-\mathrm{C} 14,-\mathrm{C} 15,-\mathrm{C} 31)$ come from the "smashed vessel horizon," from a depth of $80-120 \mathrm{~cm}$ below the surface.

Only 1 sample (SL-C19) is from the embankment. Fine lines of pottery sherds seem to mark several construction phases or walking horizons (Figure 4A). Sample SL-C19, therefore, should date the second phase. The embankment appears to have been cut on this side in order to make room for the ash deposits.

Sample SL-C2 was the deepest, found $10 \mathrm{~cm}$ above burial E10, a primary burial in the leveled compact clay and sand layer of light brown color already underneath the ash deposits. For stratigraphical reasons, it was assumed that the sample from this level would represent the oldest date of mound MO1, but surprisingly it is the youngest. SL-C2, therefore, seems to date the beginning of the ash layer accumulation with the subsequent burial practices. 
A

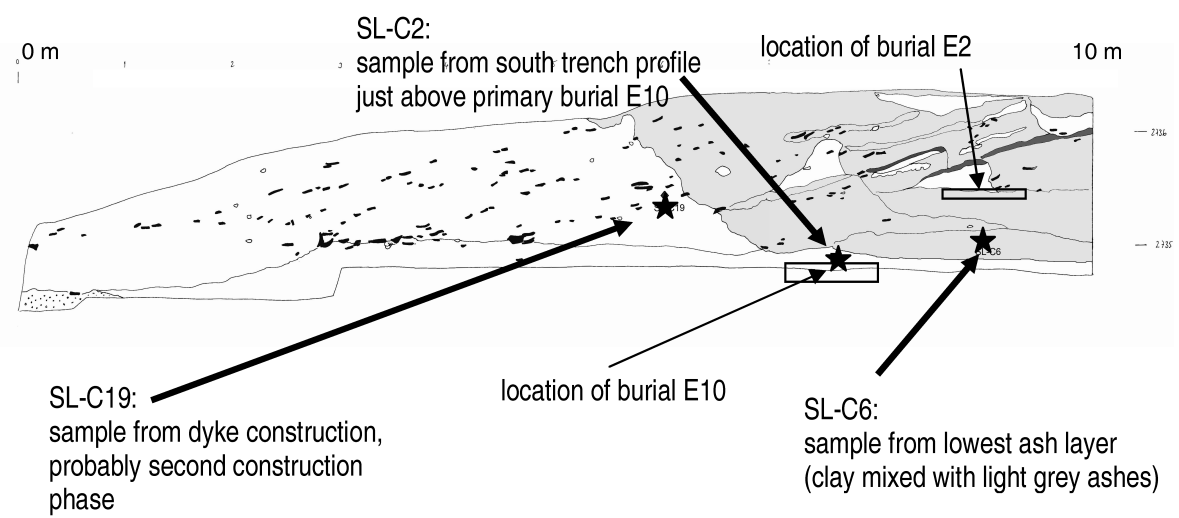

B

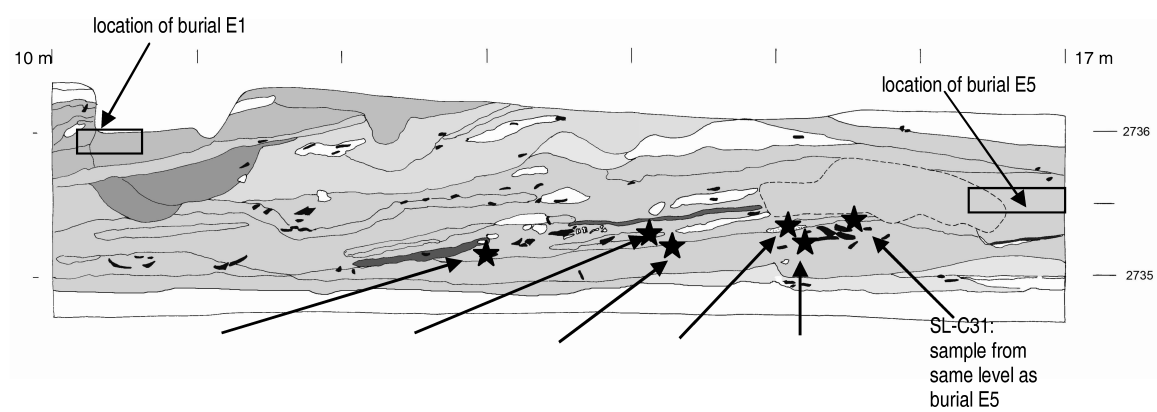

Figure 4 North profile of Trench 6 with the locations of dated samples. A) Western part of from 0-10 m. B) Eastern part from 10-17 m.

\section{METHODS}

A total of 16 samples of charcoal were taken from Trench 5 (5 samples), Trench 6 ( 9 samples), and Trench 9 (2 samples); they were dated at Gliwice Radiocarbon Laboratory using liquid scintillation (Quantulus $1220^{\mathrm{TM}}$ ) and gas-proportional counting techniques. All samples were treated with the standard sample pretreatment (Pazdur and Pazdur 1986). The standard procedure of conversion to carbon dioxide and benzene synthesis (Pawlyta et al. 1998) was then applied to the samples dated by GPC and LSC methods, respectively. All ${ }^{14} \mathrm{C}$ dates were corrected for $\delta^{13} \mathrm{C}$ (Stuiver and Polach 1977), using the assumed value of $-25 \%$. Conventional dates were then calibrated using OxCal 3.10 (Bronk Ramsey 1995, 2001) and the IntCal04 calibration curve (Reimer et al. 2004). We decided not to use the SHCal04 calibration curve (McCormac et al. 2004), because the explored site is located very close to the January location of the Intertropical Convergence Zone $\left(17^{\circ} 35^{\prime} \mathrm{S}, 65^{\circ} 56^{\prime} \mathrm{E}\right)$. The results $\left({ }^{14} \mathrm{C}\right.$ and calibrated dates) are shown in Table 1. 
Table 1 Conventional ${ }^{14} \mathrm{C}$ and calibrated dates of the samples from Santa Lucía.

\begin{tabular}{|c|c|c|c|c|c|c|c|}
\hline \multirow{2}{*}{$\begin{array}{l}\mathrm{Nr} \\
\text { Tren }\end{array}$} & \multirow{2}{*}{$\begin{array}{l}\text { Sample name } \\
\text { ch } 5\end{array}$} & \multirow{3}{*}{$\begin{array}{l}\text { Lab nr } \\
\text { Gds-376 }\end{array}$} & \multirow{3}{*}{$\begin{array}{l}\begin{array}{l}\text { Age }{ }^{14} \mathrm{C} \\
(\mathrm{BP})\end{array} \\
2350 \pm 50\end{array}$} & \multicolumn{2}{|c|}{$\begin{array}{l}\text { Calibrated age range } \\
68 \% \text { cal AD/BC }\end{array}$} & \multicolumn{2}{|c|}{$\begin{array}{l}\text { Calibrated age range } \\
95 \% \text { cal AD/BC }\end{array}$} \\
\hline & & & & & & & \\
\hline 1 & SL-C22 & & & $520-380 \mathrm{BC}$ & $68.2 \%$ & $\begin{array}{l}750-350 \mathrm{BC} \\
300-200 \mathrm{BC}\end{array}$ & $\begin{array}{r}90.5 \% \\
4.9 \%\end{array}$ \\
\hline 2 & SL-C34 & Gds-373 & $2275 \pm 40$ & $\begin{array}{l}400-350 \text { BC } \\
290-230 \text { BC }\end{array}$ & $\begin{array}{l}35.8 \% \\
324 \%\end{array}$ & $410-340 \mathrm{BC}$ & $\begin{array}{l}42.6 \% \\
52.8 \%\end{array}$ \\
\hline 3 & SL-C37 & Gds-372 & $2130 \pm 40$ & $\begin{array}{l}350-320 \mathrm{BC} \\
210-90 \mathrm{BC}\end{array}$ & $\begin{array}{r}6.2 \% \\
62.0 \%\end{array}$ & $\begin{array}{l}360-290 \mathrm{BC} \\
240-40 \mathrm{BC}\end{array}$ & $\begin{array}{l}16.1 \% \\
79.3 \%\end{array}$ \\
\hline 4 & SL-C20 & Gds-370 & $2465 \pm 40$ & $\begin{array}{l}760-680 \text { BC } \\
670-610 \text { BC } \\
600-510 \text { BC }\end{array}$ & $\begin{array}{l}23.4 \% \\
17.7 \% \\
27.1 \%\end{array}$ & $770-410 \mathrm{BC}$ & $95.4 \%$ \\
\hline 5 & SL-C24 & Gd-15964 & $2670 \pm 85$ & 930 & $68.2 \%$ & $1050-500 \mathrm{BC}$ & $95.4 \%$ \\
\hline Tre & nch 6 & & & & & & \\
\hline 6 & SL-C31 & Gd-16377 & $3050 \pm 150$ & $\begin{array}{l}1490-1470 \mathrm{BC} \\
1460-1080 \mathrm{BC} \\
1070-1050 \mathrm{BC}\end{array}$ & $\begin{array}{r}1.2 \% \\
65.9 \% \\
1.0 \%\end{array}$ & $1650-900 \mathrm{BC}$ & $95.4 \%$ \\
\hline 7 & SL-C12 & Gds-377 & $2375 \pm 50$ & $540-390$ BC & $68.2 \%$ & $\begin{array}{l}750-680 \text { BC } \\
670-630 \text { BC } \\
600-370 \text { BC }\end{array}$ & $\begin{array}{r}11.8 \% \\
3.6 \% \\
80.0 \%\end{array}$ \\
\hline 8 & SL-C14 & Gd-15965 & $2040 \pm 75$ & $\begin{array}{l}170 \text { BC-AD } 30 \\
\text { AD } 40-50\end{array}$ & $\begin{array}{r}65.8 \% \\
2.4 \%\end{array}$ & $\begin{array}{c}350-300 \mathrm{BC} \\
210 \text { BC-AD } 130\end{array}$ & $\begin{array}{r}3.2 \% \\
92.2 \%\end{array}$ \\
\hline 9 & SL-C15 & Gds-379 & $2340 \pm 50$ & $510-360$ BC & $68.2 \%$ & $\begin{array}{l}750-600 \text { BC } \\
550-350 \text { BC } \\
300-200 \text { BC }\end{array}$ & $\begin{array}{r}5.7 \% \\
80.1 \% \\
9.6 \%\end{array}$ \\
\hline 10 & SL-C9 & Gds & $2290 \pm 40$ & $\begin{array}{l}400-350 \text { BC } \\
290-230 \text { BC }\end{array}$ & $\begin{array}{l}46.1 \% \\
22.1 \%\end{array}$ & $\begin{array}{l}410-340 \mathrm{BC} \\
320-200 \mathrm{BC}\end{array}$ & $\begin{array}{l}52.2 \% \\
43.2 \%\end{array}$ \\
\hline 11 & SL-C11 & Gds-371 & $2355 \pm 40$ & $\begin{array}{l}510-430 \text { BC } \\
420-380 \text { BC }\end{array}$ & $\begin{array}{l}33.7 \% \\
34.5 \%\end{array}$ & $\begin{array}{l}730-690 \mathrm{BC} \\
550-360 \mathrm{BC}\end{array}$ & $\begin{array}{r}4.2 \% \\
91.2 \%\end{array}$ \\
\hline 12 & SL-C6 & 2 & 220 & $360-190$ BC & $68.2 \%$ & $400-110 \mathrm{BC}$ & $95.4 \%$ \\
\hline 13 & SL-C & Gd & & 200 & $68.2 \%$ & $0 \mathrm{BC}$ & $95.4 \%$ \\
\hline 14 & SL-C19 & Gd-18394 & $2750 \pm 130$ & $\begin{array}{l}1120-1100 \text { BC } \\
1090-790 \text { BC }\end{array}$ & $\begin{array}{r}1.4 \% \\
66.8 \%\end{array}$ & $1350-500 \mathrm{BC}$ & $95.4 \%$ \\
\hline & nch 9 & & & & & & \\
\hline 15 & SL-C41 & Gds -378 & $2500 \pm 50$ & $\begin{array}{l}770-720 \text { ВC } \\
700-540 \text { ВC }\end{array}$ & $\begin{array}{l}15.2 \% \\
53.0 \%\end{array}$ & $\begin{array}{l}790-480 \text { BC } \\
470-410 \text { BC }\end{array}$ & $\begin{array}{r}89.7 \% \\
5.7 \%\end{array}$ \\
\hline 16 & SL-C47 & Gds-374 & $2080 \pm 35$ & $\begin{array}{l}170-130 \mathrm{BC} \\
120-40 \mathrm{BC}\end{array}$ & $\begin{array}{l}19.1 \% \\
49.1 \%\end{array}$ & $200 \mathrm{BC}-\mathrm{AD} 1$ & $95.4 \%$ \\
\hline
\end{tabular}

\section{RESULTS AND DISCUSSION}

Trench 5: The results of calibration for the 5 samples collected from Trench 5 are presented in Figure 5. For these samples, we have clear stratigraphic information:

- Samples SL-C22, -C34, and -C37 come from the same locus and belong to the same phase linked with the use of the small hearth (called provisionally the "domestic hearth phase").

- Sample SL-C34 is older than the "domestic hearth phase."

- Sample SL-C37 is older than SL-C34. 
A

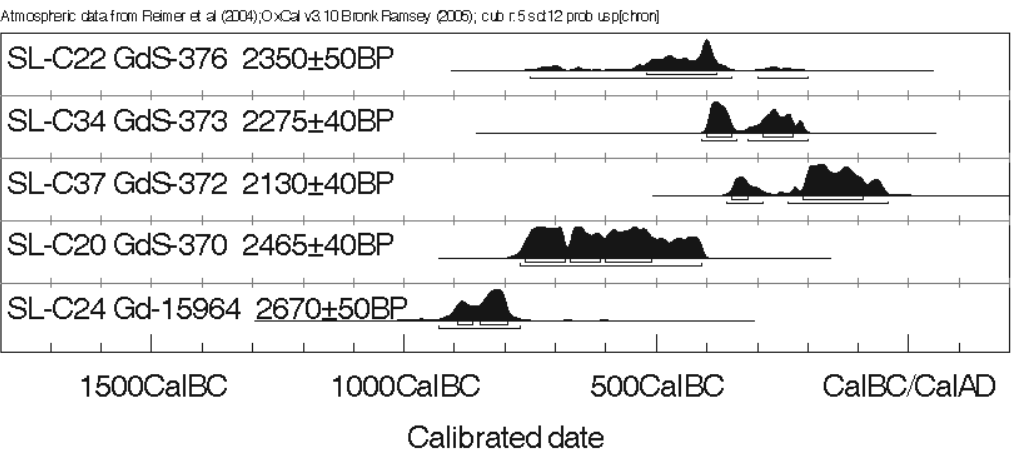

B

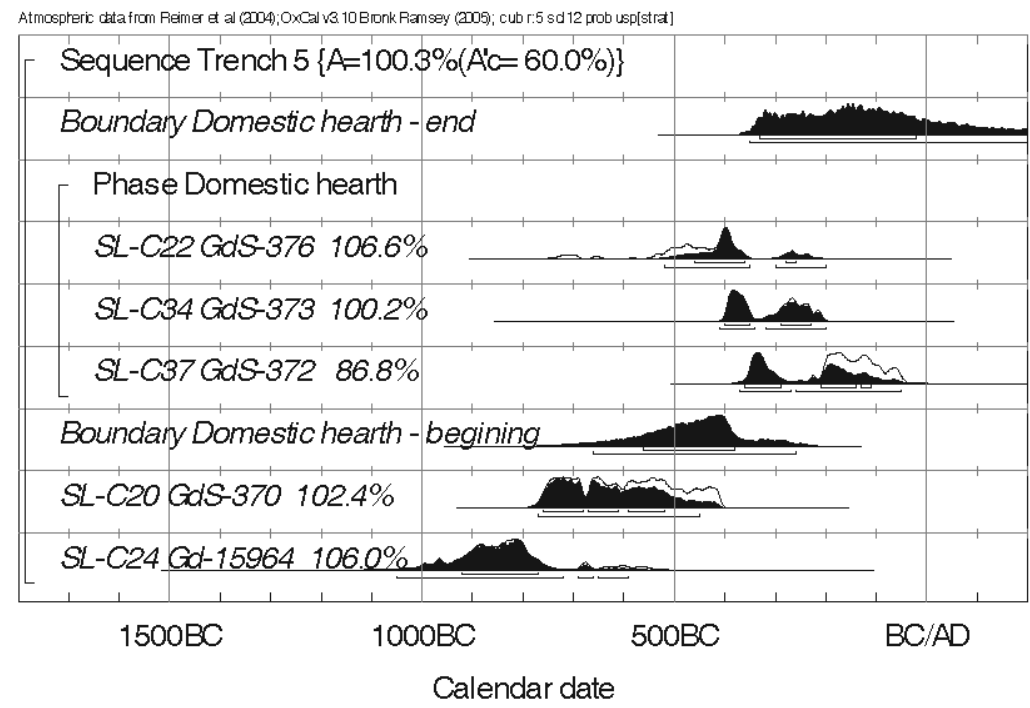

Figure 5 Calibration results of the individual ${ }^{14} \mathrm{C}$ dates for the samples from Trench 5

Therefore, we decided to construct a simple model that combines the ${ }^{14} \mathrm{C}$ dates and the stratigraphic data. The "domestic hearth phase" and the other 2 dates create a sequence of events. In this model, the dates of the samples SL-C22, -C34, and -C37 give us information about a phase with boundaries. We also added a query about the time span of the "domestic hearth phase" to this model.

The calculations for the probability distributions in calendar age using this model are shown in Figure 5B. Especially interesting are the results for the "domestic hearth phase"- the probability distributions for the beginning, the end and the possible time span of this phase (see Figure 6). The beginning of the "domestic hearth phase" is quite well-defined: It occurred between 560 and 380 BC with a probability of $68.2 \%$, but most likely around $410 \mathrm{BC}$ (maximum of the probability distribution). The end of this phase is not distinctly defined. We may only state that it occurred between 340 and $40 \mathrm{BC}$ with a probability of $68.2 \%$. There are 2 reasons for this result. First, we analyzed the uppermost layer, and there is no information about events after the end of this phase. Second, the shape of the calibration curve causes 2 possible calendar age intervals. 

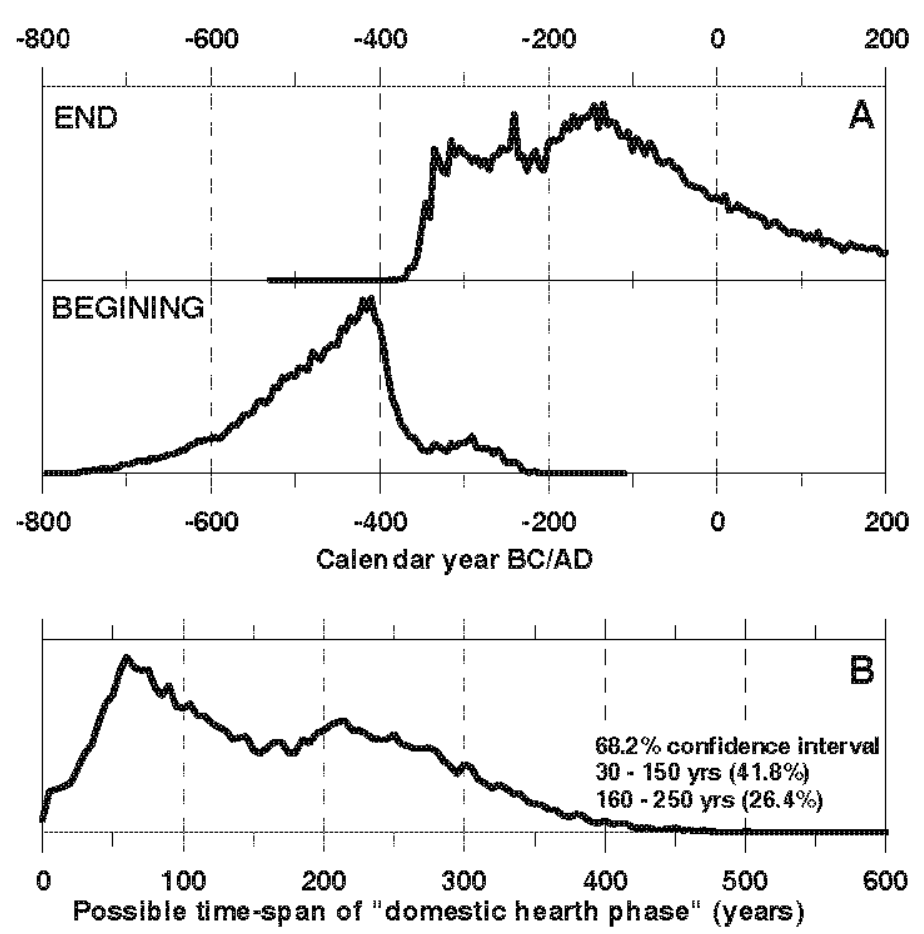

Figure 6 Probability distributions of the beginning and the end of the "domestic hearth phase" obtained with the constructed chronological model (A) as well as a probability distribution of the possible time span of the phase (B).

However, the probability distribution of the possible time span gives us additional information. We may notice that the distribution has 2 clear maxima: the first around $70 \mathrm{yr}$ and the second, with smaller probability, around $200 \mathrm{yr}$. It is an effect of the shape of the calibration curve, and it should be interpreted as 2 time-span alternatives. Based upon archaeological observations on the use life of domestic hearths, however, we may assume a time span of no longer than 70-100 $\mathrm{yr}$ for this phase.

Trench 6: The probability distributions of the calibrated ${ }^{14} \mathrm{C}$ dates of the samples from Trench 6 are presented in Figure 7. Almost all samples derive from ash layers (refuse dump) and they are presented according to their depth. There are 2 exceptions: SL-C2, which comes from the primary burial (E10) found below the ash layers, and SL-C19, which stems from the embankment. We decided to put these 2 dates at the bottom, because they are connected with strata, which according to their localization should be older than the ash layers.

The results for samples SL-C31 to SL-C6 seem to present a reversed or mixed stratigraphy and suggest a restorage of old ash deposits. This hypothesis is confirmed by the fact that the burials found in the ashes are partially destroyed (or they may be secondary burials). The date of the SL-C2 sample, therefore, is the terminus post quem for the restorage.

\section{Comparison of the Results from All Trenches}

It should be emphasized that the results for all 3 trenches are consistent. We may also notice a few interesting links between the dates of all trenches that point to different contemporary activities in the site (see Figure 8): 


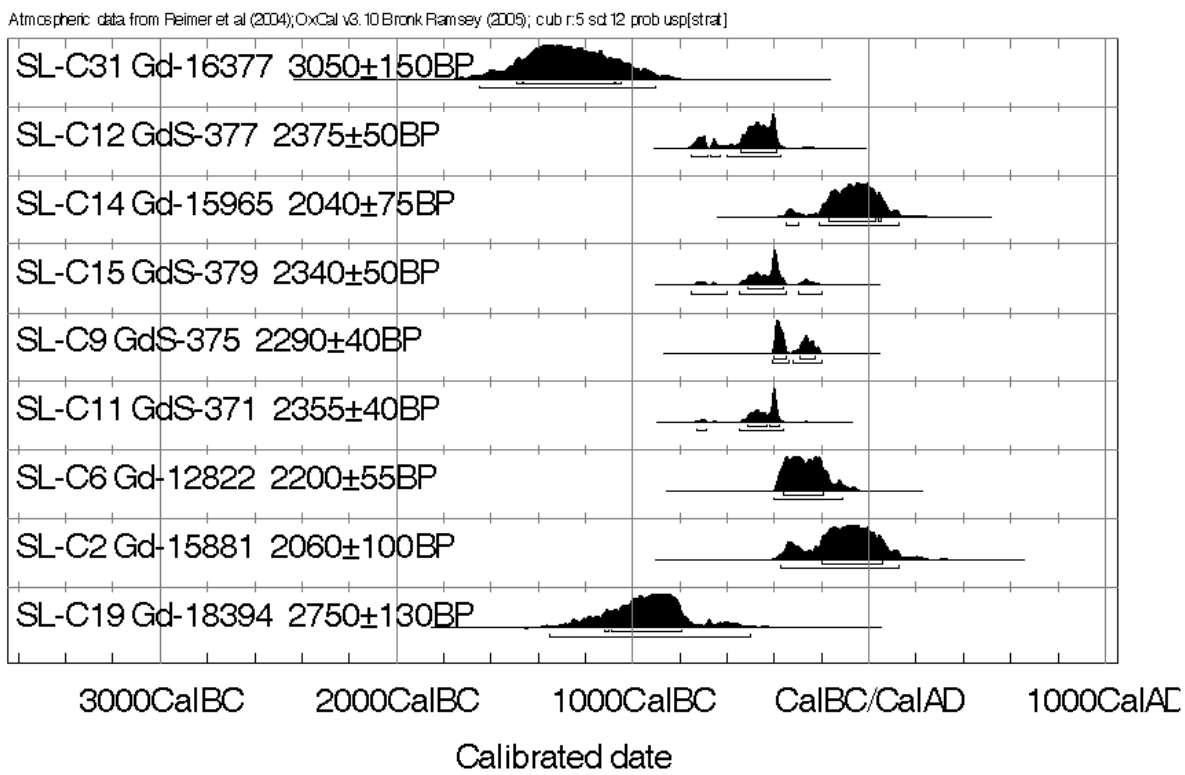

Figure 7 Calibration results of the individual ${ }^{14} \mathrm{C}$ dates for the samples from Trench 6

1. Some of the results from the ash layers of Trench 6 (SL-C15, -C9, -C12, -C11) are contemporary with the "domestic hearth phase" according to data from Trench 5 . We can draw the conclusion that most of the ash layers from Trench 6 were produced during the use of the "domestic hearth" (and probably firing facility H99) in Trench 5 around 410-340 BC.

2. Samples SL-C20 (Trench 5) and SL-C41 (Trench 9) seem to come from the same stratum of a 50- to 70-cm-thick fill layer that is observed within a 100-m distance in the center of the site. The curves of the 2 samples are almost identical. This observation points to a massive leveling activity of at least a part of the settlement around 770-480 BC.

3. Waste pit $\mathrm{H} 21$ from Trench 9 is dated by sample SL-C47. This sample also seems to date house C5 on the surface. It may, therefore, be treated as the youngest occupation phase. It is younger than the "domestic hearth phase," but it is in clear accordance with SL-C2, the youngest date from Trench 6, which is the terminus post quem for the restorage activities (see also SL-C14). The restorage of the ashes and the use of house $\mathrm{C} 5$ and waste pit $\mathrm{H} 21$ can therefore be considered to be contemporary during $350 \mathrm{BC}-\mathrm{AD} 1$.

4. Sample SL-C24 from Trench 5 and SL-C19 from Trench 6 can also be seen as roughly contemporary, dating to $1050-500 \mathrm{BC}$. The second phase of the embankment in Trench 6 , therefore, took place between the use of the house floor packages 11 and 7/7A from Trench 5 .

\section{Santa Lucía Chronology on the Background of Wider Archaeological Context}

Brockington et al. (1995:167) established an Early Phase A from 1100-800 BC, Early Phase B from 800-500 BC, Middle Phase A from 500-200 BC, and Middle Phase B from 200 BC-AD 200 in Sierra Mokho in the Central Valley. The Late Formative Phase (AD 200-550) is already contemporary with the polychrome Tupuraya style of the Early Intermediate period. These phases are entirely based on the ceramic sequence of Sierra Mokho, although, on the other hand, they note quite a stable ceramic tradition during all of the Formative period (Brockington et al. 1987:42). It should be mentioned that the ceramic material stems from excavations in artificial layers of $20 \mathrm{~cm}$ (Brockington et al. 1987:9), a method that is likely to blur any exact stratigraphy. No activity areas were dated nor 


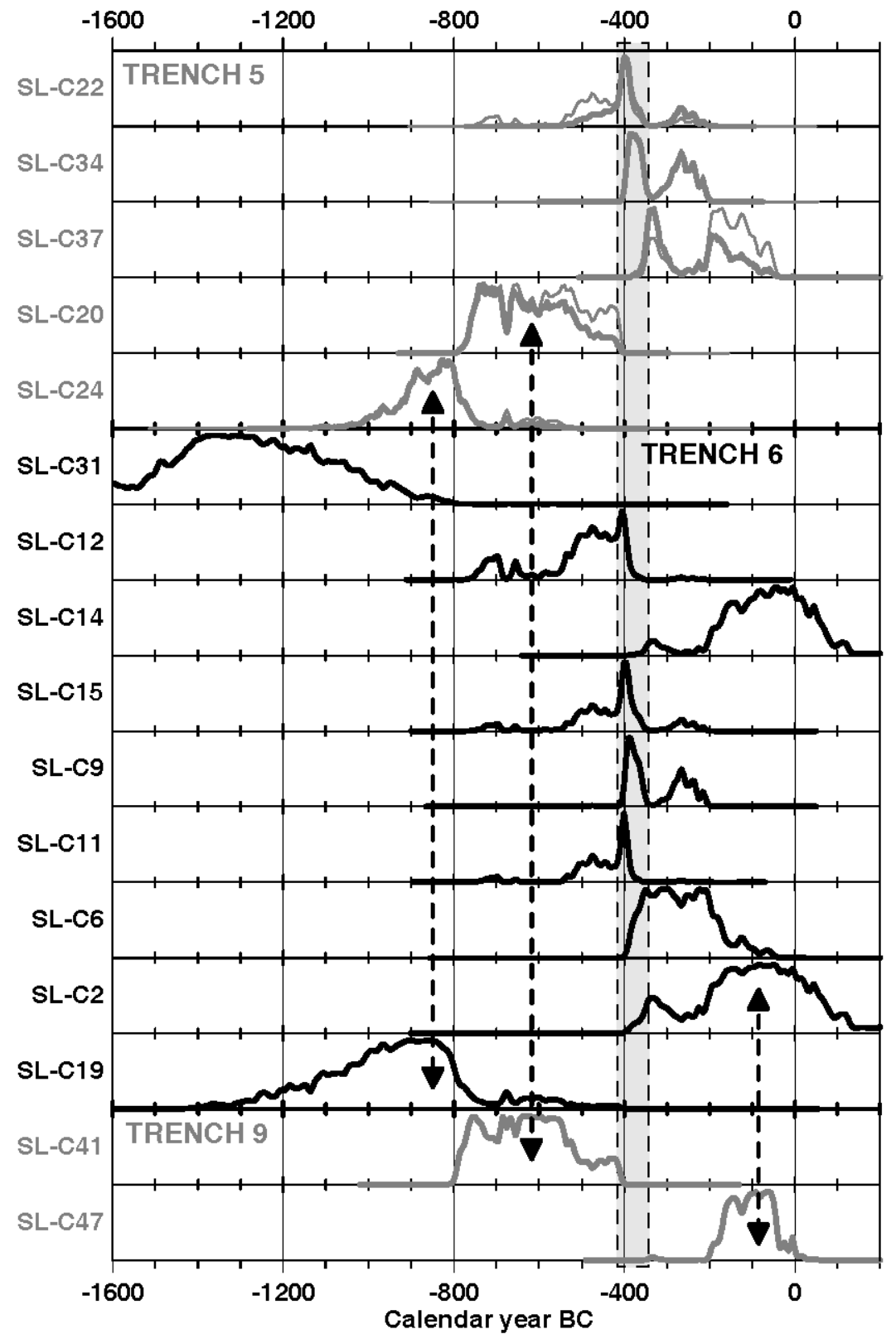

Figure 8 Comparison of the results from Trench 5, Trench 6, and Trench 9

references to possible social developments made. Although their established phases are not necessarily wrong, they seem somewhat arbitrary and the authors surely do not attempt to explain or interpret any of the changes seen in the ceramic sequence.

According to the stratigraphy and the results of the ${ }^{14} \mathrm{C}$ dates, a 3-phased chronology of Santa Lucía is also possible. For the purposes of crossdating and comparisons with other regions, the authors of this paper opted for an adaptation of the regional chronology to the Highland or even pan-Andean 
chronology (see Stanish 2003; Kaulicke 1998; for this reason, the Middle Formative of Brockington et al. [1985, 1987, 1995] is now the Late Formative).

In Santa Lucía, the phases are the following: an Early phase (Santa Lucía I) may be proposed as dating before $1000 \mathrm{BC}$, according to the undated layers in Trench 5 and the questionable date of SLC31, respectively (Figure 8). While the beginning of the occupation of Santa Lucía is still unclear, this early phase can be crossdated by ceramics from the Formative site of Choroqollo in the neighboring valley, dated to cal BC 1440-1310 (1 б; KN-5374; Gabelmann 2001).

A Middle phase (Santa Lucía II) may be established beginning around 1000-950 BC with the dates SL-C19 and SL-C24. They stand for the second phase of the embankment in Trench 6 and the accumulation of the fill layer between the house floors 11 and 7/7A. Moreover, based upon the dates SLC20 and SL-C41, we may suppose that a huge restructuring activity took place in the center of the site at about 750-480 BC, at the turn of the phase Santa Lucía II to Santa Lucía III. This 50- to 70$\mathrm{cm}$-thick layer was detected in Trench 5 and Trench 9 at a distance of about $100 \mathrm{~m}$.

The subsequent Santa Lucía III phase, beginning around 500 BC, is characterized by a spatial division of the site into a residential and a workshop sector, which suggests an increasing production mode. The "domestic hearth phase" from Trench 5 belongs to this phase as does the redeposition of the ashes in mound MO1 (Trench 6) about $200 \mathrm{yr}$ later, at the time of the use of house C5 and waste pit $\mathrm{H} 21$ as dated by the samples SL-C47 and SL-C2.

Interestingly, during this phase we can see an increasing exchange of ceramics between Santa Lucía and Sierra Mokho (Gabelmann 2008). This social and economic change may have influenced more sites in the valleys. This is probably the change in the ceramic sequence observed by Brockington et al. but they were not able to further explain this event. However, it seems that this development is due to an economic consolidation of the valleys as an answer to the sociopolitical events that took place in Chiripa and the circum Titicaca Lake area. At $500 \mathrm{BC}$, the rise of highly ranked societies led to the formation of several regional centers around the lake and to an increasing trade system for prestige and staple goods that likely affected the eastern valleys (Stanish 2003:137).

Due to the difficult calibration situation in the 1st millennium BC (between 800-400 BC), we are not able to define the beginning of the spatial changes in Santa Lucía more precisely. The end of the settlement of Santa Lucía also remains unclear due to superficial erosion.

\section{CONCLUSIONS}

The ${ }^{14} \mathrm{C}$ dates from the different sectors (or trenches) of the site are clearly related and give a consistent view of the chronology of the investigated part of Santa Lucía. Also, the results confirm the existing time span of the Formative period in the Bolivian valleys so far, showing an occupation from at least 1000 BC to AD 50 in Santa Lucía.

Even though these new results do not differ too much from the existing chronology, we do have a clearer picture about the social processes in the Formative period in the south-central Andes. Nevertheless, with the application of ${ }^{14} \mathrm{C}$ dating it should not always be the first goal to gain the "earliest" dates in a region, but to be able to link social processes with a defined date in the absolute chronology. This enables us to compare sequences of prehistoric events over a vaster region and to detect links or triggering effects between them. ${ }^{14} \mathrm{C}$ dating is a necessary instrument for confirming developed theories and models and is, therefore, an important contribution for understanding the Formative period processes that still need to be investigated, be it in the Bolivian valleys, the highlands or the neighboring regions in Peru, northern Chile, or northwest Argentina in the future. 


\section{REFERENCES}

Bronk Ramsey C. 1995. Radiocarbon calibration and analysis of stratigraphy: the OxCal program. Radiocarbon 37(2):425-30.

Bronk Ramsey C. 2001. Development of the radiocarbon calibration program. Radiocarbon 43(2A):355-63.

Brockington DL, Pereira Herrera D, Sanzetenea Rocha R, Céspedes Paz R, Perez C. 1985. Informe Preliminar de las Excavaciones en Sierra Mokho y Chullpa Pata (Periodo Formativo). Cuadernos de Investigación, Serie Arqueología No. 5, Cochabamba.

Brockington DL, Pereira Herrera D, Sanzetenea Rocha R, Céspedes Paz R, Perez C. 1987. Formative Period Archaeological Sequences in Cochabamba, Bolivia. Report to the National Geographic Society. Washington DC.

Brockington DL, Pereira Herrera D, Sanzetenea Rocha R, Muñoz M. 1995. Estudios Arqueológicos del Periodo Formativo en el Sur-Este de Cochabamba 19881989. Cuadernos de Investigación, Serie Arqueología No. 8, Cochabamba

Gabelmann OU. 2001. Choroqollo-producción de cerámica e intercambio de bienes durante el Período Formativo. Un ejemplo del Valle Santivańez, Cochabamba. Textos Antropológicos 13(1-2):197-229.

Gabelmann OU. 2008. Keramikproduktion in Santa Lucía. Ein Blick auf die "Peripherie" des Formativums im südzentralen Andenraum [PhD dissertation]. Berlin: Freie Universität.

Ibarra Grasso DE. 1962. Die bolivianische Vorgeschichte. Saeculum 13(4):330-54.

Ibarra Grasso DE, Querejazu Lewis R. 1986. 30.000 años de Prehistoria en Bolivia. La Paz, Cochabamba.

Kaulicke P. 1998. Perspectivas regionales del Período Formativo en el Perú: una introducción. In: Kaulicke P, editor. Perspectivas Regionales del Período Formativo en el Perú. Boletín de Arqueología PUCP, No. 2, Lima. p 9-13.

McCormac FG, Hogg AG, Blackwell PG, Buck CE, Higham TFG, Reimer PJ. 2004. SHCal04 Southern Hemisphere calibration, 0-11.0 cal kyr BP. Radiocarbon 46(3): 1087-92.

Pawlyta J, Pazdur A, Rakowski A, Miller B, Harkness DD. 1998. Commissioning of Quantulus $1220^{\mathrm{TM}} \mathrm{liq}$ uid scintillation beta spectrometer for measuring ${ }^{14} \mathrm{C}$ and ${ }^{3} \mathrm{H}$ at natural abundance levels. Radiocarbon 40(1):201-9.
Pazdur A, Pazdur MF. 1986. Aparatura pomiarowa LaboratoriumC-14 w Gliwicach. Do wiadczenia konstrukcyjne i eksploatacyjne (The measuring equipment of the Gliwice Radiocarbon Laboratory. Experience gathered in the construction and exploitation). Zeszyty Naukowe Politechniki Slaskiej, Seria Matematyka-Fizyka, Z. 46. Geochronometria 1:5569.

Pereira Herrera D, Brockington DL. editors. 2000. Investigaciones Arqueológicas en las Tierras Tropicales del Departamento de Cochabamba-Bolivia. Cuadernos de Investigación, Serie Arqueología No. 9, Cochabamba.

Reimer PJ, Baillie MGL, Bard E, Bayliss A, Beck JW, Bertrand CJH, Blackwell PG, Buck CE, Burr GS, Cutler KB, Damon PE, Edwards RL, Fairbanks RG, Friedrich M, Guilderson TP, Hogg AG, Hughen KA, Kromer B, McCormac G, Manning S, Bronk Ramsey C, Reimer RW, Remmele S, Southon JR, Stuiver M, Talamo S, Taylor FW, van der Plicht J, Weyhenmeyer CE. 2004. IntCal04 terrestrial radiocarbon age calibration, 0-26 cal kyr BP. Radiocarbon 46(3):102958.

Rice PM. 1987. Pottery Analysis. A Sourcebook. Chicago: University of Chicago Press. 584 p.

Rydén S. 1961. Complementary notes on Pre-Tiahuanaco site Chullpa Pampa in Cochabamba area and notes on one Tiahuanaco site in La Paz, Bolivia. Ethnos 26: $40-55$.

Stanish C. 2003. Ancient Titicaca. The Evolution of Complex Society in Southern Peru and Northern Bolivia. Berkeley: University of California Press. 354 p.

Stuiver M, Polach HA. 1977. Discussion: reporting of ${ }^{14} \mathrm{C}$ data. Radiocarbon 19(3):355-63.

Walter H. 1966. Beiträge zur Archäologie Boliviens. Die Grabungen des Museums für Völkerkunde Berlin im Jahre 1958. Achäologische Studien in den Kordilleren Boliviens II. Berlin: Dietrich Reimer.

Ziółkowski MS, Pazdur MF, Krzanowski A, Michczyński A, editors. 1994. ANDES. Radiocarbon database for Bolivia, Ecuador and Peru. Warsaw, Gliwice: Andean Archaeological Mission of the Institute of Archaeology, Warsaw University; Gliwice Radiocarbon Laboratory of the Institute of Physics, Silesian Technical University. 